\title{
Corporate Governance, Small Medium Enterprises (SMEs) and Firm's Performance: Evidence from Construction Business, Construction Industry Development Board (CIDB) Malaysia
}

\author{
Malik Azhar Hussain ${ }^{1} \&$ Abdul Razak Abdul Hadi ${ }^{1}$ \\ ${ }^{1}$ Universiti Kuala Lumpur Business School, Kuala Lumpur, Malaysia \\ Correspondence: Malik Azhar Hussain, Universiti Kuala Lumpur Business School, Kuala Lumpur, Malaysia. \\ E-mail: malik_azhar12@yahoo.com
}

Received: November 11, 2017

Accepted: December 18, 2017

Online Published: January 15, 2018

doi:10.5539/ijbm.v13n2p14

URL: https://doi.org/10.5539/ijbm.v13n2p14

\begin{abstract}
Utilising agency theory, this research used primary data to identify the depth of the underlying structure and test the relationship between the variables. In addressing these issues, the study applied logistic regression to data collected from questionnaires, the study identifies the underlying structure of 9 items via factor analysis. The relationships between board committee size, board composition, remuneration committee, gender diversity, risk management committee, ownership concentration, audit committee, duality and firm's performance measured by return on assets (ROA) were analysed by using logistic regression with the application of SAS(9.4) on data collected from 380 small and medium enterprises under the Construction Industry Development Board (CIDB) Malaysia. It was found that board size, board composition, remuneration committee, risk management committee and gender diversity has no significant impact on firm's performance. While duality and audit committee have a significant positive relationship with firm's performance. Meanwhile, ownership concentration has a significant negative relationship with firm's performance. As a conclusion, the corporate governance mechanism has a significant impact on firm's performance in the CIDB construction industry in Malaysia. The contribution of this study is deemed significant as this is the first study applied on CIDB registered enterprises in the Klang Valley, using a quantitative research design.
\end{abstract}

Keywords: corporate governance mechanism, factor analysis, board composition, agency theory, firm's performance, construction industry development board (CIDB)

\section{Introduction}

Corporate governance is a technique and structure used to control business exercises of the economic system of the organization towards expanding business triumph. Corporate governance also differs from entity to entity and from country to country. The ultimate objective is to standardize and attain higher performance, which will, in turn, bring in profitability and prevent the management from trying to pursue their objectives instead of those of the company at the cost of the shareholders (Luo \& Chi, 2007). According to Solomon (2010), weak corporate governance or lack of adherence to its principles, even if it's strongest, can lead to abuses, fraud and under performance of a company. The shareholders' part for governance is to engage those executives and the auditors for the benefit of the firm and fulfill themselves to guarantee that a competent corporate structure is developedCadbury Report 1992.

Corporate governance is not easily defined due to the continuously broadening scope of the subject (Roche, 2005). According to Armstrong and Sweeney (2002), definitions vary according to contexts like cultural situations and also based on the perspectives of different researchers where some researchers argue that a company's main responsibility should be towards increasing the wealth of the shareholders (Sundaram \& Inkpen, 2004). Other researchers are of the opinion that a company has an obligation which is not limited to only shareholders, but also to the stakeholders whose contribution is highly important for the success of a company (Donaldson et al., 1997).

Rezaee (2009) came up with another definition of corporate governance, which has to do with a process by which shareholders place the responsibility of acting in their interest on the management, through the provision of a degree of confidence which is necessary for the effectiveness of the capital markets. The Cadbury Code that 
emerged in 1992 can be seen as a good example, which came into play as a result of the corporate failures of the 1980s. The recommended changes it brought to the board structure together with the procedures to make a company more accountable to the shareholders, suggested ideas that led to the increase in the number of independent directors on the board, separation of the chairmanship role from that of the CEO and the introduction of board committees (Chowdary, 2002). The World Bank Report (2012) recognized Malaysia as a regional leader in corporate governance but stated that there are plenty of rooms for improvement in the area of corporate governance (Reports on Observance Standards and Codes, 2012). There is inadequate shareholders control and protection for the Malaysian corporate sector (Kamini, 2003).

The study aims to investigate the following questions; (1) Does the corporate governance mechanism is effective on firm's performance of construction industry development board (CIDB) Malaysia? (2) Does the independent variables taken into consideration can determine firm's performance of small and medium enterprises (SMEs) of construction industry development board (CIDB) Malaysia?

To find the answers to the research questions, this study is organized into six (6) sections. Section one provides introduction, section two (2) confers literature review, section three (3) demonstrates theoretical framework, section four (4) establishes methodology, data collection and variables used in the study, section five (5) provides empirical findings, while section six (6) highlights discussions and conclusion of the current research.

\section{Literature Review}

Corporate governance channalize the vitality of ownership concentration, board structure and also impact of stakeholders on the organizations. Over more diminutive companies, managers assume to play a critical part along with forming corporate esteem frameworks that effect organizations performance from months to years. Previously, bigger organizations that separate concentrated ownership, supervisors and their controls that assumes to play a capable role (Steen, 2004). The conceptual framework of corporate governance of earlier studies supports agency theory. This theory based on the fact that stakeholders targets can be accomplished if administrator's speculation is under control (Jensen and Meckling, 1976). Company performance is found to be positively related to the directors' collective and individual attributes which are associated with access to information, effectiveness of board, observance of fiduciary responsibility and performance evaluation (Veysel and Ekrem, 2006).

Bruce and Alexander, (2002) concede that structural changes to corporate governance conventions, including stupendous execution and strategy formulation, more freedom about compelling audit reviews, effective transparency in the selection of top-executive appointments that would bring firm performance at top level. Compliance with and disclosure of good CG practices varies substantially among the different companies, and CG standards have generally improved over the period. The researcher also finds that block ownership is negatively perform against voluntary CG disclosure, while board committee size, audit firm value, cross-listing, the availability of a CG board committee, ownership of institutional and regulatory bodies are positively respond to voluntary CG disclosure listing (Collins et al., 2012).

Corporate governance in established market economies has been fabricated regularly over several centuries as a value of the economic growth of industrialized entrepreneurship (Chowdary, 2002). CG assumes a main role in the execution of MFIs and the autonomy of the board and acceptable detachment of the role of a Chief Executive Officer and board chairperson that have a positive association with performance processes (Anthony \& Kofi, 2008).

The origin of construction industry in Malaysia linked back to the British Organization. The highly qualified engineers from Britain and workers are supported by the foreign Government of Indian sub-continent to build a massive meter gauge railway track in the year 1882. The group of contractor consists of a small number of individuals from two to five people contributing facilities and working with the direction of an engineer or architect, engaged by the client (Sundaraj, 2006). The main contractors well managed and hire sub-contractors who tender for and acquire ventures to consequently leased portion of the projects in segments had been started from the beginning. It is still prevailing in present times (Sundaraj 2006; Tan, 2004). The Malaysian administration preferred learning from other developed countries like Japan and Korea and continue the struggle to stand with the developed countries of Asia. Dayabumi building is one of the best examples of that strategy (Tan, 2004).

Conversely, a Bumiputra engineering company complains that there are no actual technology transfer took place, they are also partner of Japanese contractors acclaimed that it is also just to maintain a good relationship with the government (Lavender, 1996). The tourism industry also increased rapidly due to big development projects in non-residential areas like hotels, resorts, malls and golf courses which plays a vital role in economic growth 
(BNM, 1999). During the period of 1990-1997, the constructions of building projects become double especially in the Clang Valley. Therefore, the government took preventive measures in early 1995 to address the nation about asset bubble (BNM 1999). The procedure of foreign proprietorship for residential properties become relaxed with the new rulings introduced by the Government. The purchase of a house by a foreigner above RM250,000 exempted from approval of the Foreign Investment Committee. The construction industry is affected in 2006 due to these initiatives (BNM 2007). During the period of recession, most of these entities are not able to sustain because all of the related corporations would be exaggerated, ultimately, the whole of the organizations at survival threat during the period (Tan 2004).

The Cadbury Code (1992) originates as a consequence of the corporate disasters in the 1980s in United Kingdom. It suggests modifications to the board structures and measures to make the entity more liable to the stockholders, advises growth in the number of independent directors on the board, separation of the chairman and CEO, and overview of board committees (Chowdary, 2002). The underpinning theory of the current study is Agency theory. Iskandar et al. (2011) also supports Agency theory in their research of corporate governance.

\subsection{Board Composition}

Masood et al. (2013) states that board independency have positive relationship with firm performance. Board composition is a vital mechanism of board structure, which points to the executive and non-executive directors' demonstration on the board. The agency theory and stewardship theory, both apply to board composition where boards that have more of non-executive directors are mainly grounded in agency theory which suggests that an operational board should consist of a majority of non-executive directors expected to perform higher due to their freedom from the company administration (Dalton et al. 1998).

On the other hand, the executive director representation on the board is grounded in stewardship theory as it supports the claim that leaders are good stewards and therefore, put so much effort in making profit and ensuring stakeholder returns (Donaldson and Davis, 1994). Beasley (1996) reports that boards with a mainstream of external directors justify their observing role in respect to financial reporting. Weir and Laing, (2001) stated in their study that there are a number of reasons why practical proof might be inadequate to support the positive connection that exists between non-executive directors and enactment.

\subsection{Board Size}

Masood et al. (2013) found that board size has no significant relationship with firm performance. Using panel data regression, Ujunwa (2012) points out that size of the board, CEO/Chairman duality functions are negatively related to firm performance, whereas board independence have positive impact on firm performance and corporate governance. Similarly, corporate governance research has mainly influenced by agency theory. We studied before board size by way of a variable which can make affect corporate governance performances plus financial statements in this research. That is, recognizing that the board size as well as firm size remains interconnected (Dalton et al. 1999) with board size is associated with the firm presentation (Kiel and Nicholson 2003).

Since an organization viewpoint, bigger corporations need superior boards to observe and regulate the administration's activities (Kiel and Nicholson 2003). For example, proposed through agency philosopher (Jensen 1993), an ideal edge ought to be around 8 administrators plus Lipton as well as Lorsch (1992) proposed that the extreme size of the board ought to be 10 followers, by way of the bigger records will restrict to the team subtleties also the obstruct board presentation. Another vision is about that which is not to size and it is significant, somewhat this is the quantity of outdoor administrators (Dalton et al. 1999).

\subsection{Remuneration Committee}

Muhammad et al. (2009) study found a positive relationship between directors' remuneration with the board executive committee, remuneration committee, the nomination committee and corporate governance committee. Board committees consist of audit, remuneration and nomination committees. It is acclaimed by the Cadbury report (1992) that a board should consist of separate committees for auditing of the financial statements, observing the remuneration of executive directors and engaging new directors to the board. The existence or absence of committees is offered by dummy variables in earlier studies (Laing \& Weir 1999). Dalton et al. (1998) also described the addition of remuneration committees lead to better enactment. Hence this study supports the board committee arrangement for better enactment.

\subsection{Risk Management Committee}

Risk management committee has the ability for the immediate identification, prioritization and oversaw economic risk, and in addition backing internal audit review functions of the audit review committees (Fraser \& 
Henry, 2007). The stakeholders can hope their personal satisfaction of financial instruments regulations are higher along with organizations existing RMCs over to organizations having no such committees. This may be as a result RMC oversees different financial dangers that confronted towards the firm, subsequently those financial reporting value may be significantly improved (Yatim, 2010). Research on risk management committee is very limited. Previously, majority of moments, role of risk assessment falls under audit committee review. However, Yatim (2010) proposes that the development of risk assessment board in Malaysia is not just connected with competent structure of board, extent of the entity and the unpredictability of a company's operations, but also their role linked with big 4 audit review firms which have been connected with high-quality regulations. Likewise Risk management committee has been accounted for to a competent board of directors (Yatim, 2010).

\subsection{Gender Diversity}

Wang and Clift (2009) explain that women directorship has no significant impact on firm performance. The share of females farming the position of the board of administrators is going to be decreased from the year 2005 till 2007 at the speed of $10.2 \%, 7.6 \%$, and $5.3 \%$ severally. Though, this share is marginally boosted in 2008 to $7.41 \%$ (according to kpwkm). The shortage of the contribution of Malaysian women directorship in important board decisions is disclosed at the World Economic Forum's in World Gender Gap Index 2009, wherever Malaysia gets 5 places to a hundred and one from out of one hundred fifteen countries surveyed linked to a recent year (Hunt, 2010). It is consistent with an investigation carried out by Soares, et. al., (2010) that presented Malaysia is within the 9th rank of female on the board of director's level between Asia Pacific organizations.

Moreover, analysis by Catalyst (2008) demonstrated that on the average, Forty five hundred corporations with a lot of ladies administrators had considerably accomplished big financial targets than those with the smallest amount by $53 \%$ over return on equity, $42 \%$ over return with sales, $66 \%$ over return on invested capital. (Julizaerma \& Zulkernain 2012) demonstrates the policy of Malaysian government for minimum requirement of 30 percent women directorship in the board decisions of the financial departments. Additionally, women directorship has significant relation on company's' profitability in case of categorical data which is consistent with (Maran \& Indraah, 2009). While Julizaerma and Zulkarnain. (2012) find a significant positive relation between firm performance and women directorship.

\subsection{Duality}

Masood et al. (2013) shows that an independent board and CEO duality have correspondingly positive and negative association with firm performance. Joshua and Nicholas (2007), explains that board size, board composition, management skill level, CEO duality, inside ownership, family business, and foreign ownership have significant positive impacts on profitability. Chris et al. (2009), highlight that there is a large amount of table discussion from board of directors in the process of financial structure decision-making, but found that there is no relationship between board of directors participation and corporate governance (board size, board independence and CEO duality). Ujunwa (2012) found that board size, CEO duality and gender diversity are negatively linked to firm performance, whereas board nationality, board ethnicity and the number of board members with a $\mathrm{PhD}$ qualification are found to impact positively on firm performance.

\subsection{Ownership Concentration}

Foreign investors tend to speculate in corporations with smart company governance as a result of effective company governance reduces agency cost and thus, declines financial hazards (Leuz et al., 2008). Investors of financial institutions are typically have vital number of stocks within the corporations and want to safeguard their reserves. Giant group of investors have a robust incentive to observe administrators plus also the power to discipline the managers (Chang, 2003). Lei and Teen (2005) notice a positive correlation between financial institutions possession and company governance points for community corporations in the territory. Chang (2003) stated that considerable amount of financial institution investors are middle operators for final business owners. They need quite totally different incentives plus risk preferences as a result of they are subject to scrutiny through the ultimate homeowners thus, would perform higher.

McConaughny et al. (2001) notice that corporations transferred from spouse and family are worthy and reasonable by nature of the business. Yammeesri and Lodh (2001) notice that company profitability are positively correlated with spouse \& family possession. Kole and Mulherin (1997) study corporations with federal government possession of quite thirty fifth and notice that the performances of those corporations do not seem to be considerably totally different from alternative corporations within the same trade.

\subsection{Audit Committee}


Higher business performance depends on great legislation of good governance. However, over steady with the prior researchers that found, there is a blend of affiliation between useful review work of audit committee and firm performance (Hermalin \& Weisbach, 1991). Through the observation of major stakeholders of business organizations that are more concerned with financial capabilities in the establishment of audit committee team members (Davidson et al, 2004). The Malaysian Code on Corporate Governance also states that members of the audit committee should have a sufficient understanding of financial reporting issues. MCCG suggested that minimum one member of audit review committees should be enrolled under the local accounting legislative council, mainly Malaysian Institute of Accountants, or should not be less than three years of experience after getting certification from a legislative body and must hold membership of prescribed accounting bodies (Shamser \& Zulkarnain, 2001). A significant relationship exists between the extents of audit review committee with great experience of accounting, recurrence of the meeting in a year with profitability management practices (Saleh et al., 2007).

However, the aggregate number roundtable meetings rely on the terms of reference and the unpredictability of the organization's operations. Not less than three or four face to face meetings should be corresponded with the audit review cycle and the timing about distributed twelve-month audit reports furthermore to other council meetings held in response to the available conditions throughout the financial year (Malaysian Code on Corporate Governance 2000).

\subsection{Firm's Performance}

The current study uses firm performance as dependent variable. (Saleh, 2012) demonstrates that firm performance is negatively related to Corporate Governance reporting. Kevin et al. (1994) states that the level of return on assets raises when the concentrated ownership achieves a level of $68.2 \%$, after that, return on assets declines. Morck et al. (1988), states that the entity role of performance inclines to increase when administration ownership tends to rise from $0 \%$ to $5 \%$, and additionally, it declines when administration ownership expands from $5 \%$ to $25 \%$.

The following is the firm performance measures investigated in this study, namely; return on assets (ROA), which is also considered as representative for profitability returns and market returns. Bilal et. al., (2013) reveals that there is a significant impact on board size, CEO/Chairman Duality on ROA, and there is an insignificant impact of Board Composition on ROA, whereas Return on asset that is also an accounting measure, is used to measure the productivity of assets engaged in firm performance (Haniffa \& Hudaib, 2006). Less than $4 \%$ of Brazilian firms have "good" corporate governance practices, and that firms with better corporate governance have significantly higher (return on assets) performance (Andre et. al. 2005).

\section{Theoretical Framework}

On the basis of literature review, board committee size, board composition, remuneration committee, gender diversity, risk management committee, ownership concentration, audit committee and duality have been statistically found as having influence on firm's performance. This complete set of governance mechanism are considered as independent variables in the context of framework. The firm's performance is selected as dependent variable. The association among each of these explanatory variables and firm's performance are theorized as follows,

H1: Board composition is positively related to firm's performance.

H2: Board size is positively related to firm's performance.

H3: Remuneration committee is negatively related to firm's performance.

H4: Risk management committee is positively related to firm's performance.

H5: Gender diversity is positively related to firm's performance.

H6: Duality is negatively related to firm's performance.

H7: Ownership concentration is negatively related to firm's performance.

H8: Audit committee is positively related to firm's performance.

The present research consists of two control variables including board size (Julizaerma and Zulkernain, 2012) and duality (Masood et. al. 2013; Lu et. al. 2015) with the context of prior studies. These governance variables have been identified to have an influence on firm's performance and therefore, essential to be controlled in the current research. 


\section{Methodology}

The study uses quantitative approach utilizing primary data with non-probability convenience sampling procedure involving a sample size of 380 companies. Kundari et al. (2012) states that convenient sampling is a technique where respondents answered to survey questionnaires that were intended to complete. Conveneince sampling is the best type of sampling to overcome the restriction of duration and cost of the research (Manakotla \& Jauhari, 2007). The recommended sample size (S) is 380 based upon Krejcie and Morgan's Table (1970).

The return on asset variable is analyzed on a nominal scale. This variable is dichotomous in nature fulfilling the basic assumption of logistic regression. Return on asset considered 1 if increases than 5 percent $(\mathrm{ROA}>5 \%)$ and considered 0 if decreases than 5 percent $(\mathrm{ROA}<5 \%$ ). (Loth, 2005) proposed that as a rule of thumb, investors are interested in those companies which have ROA more than 5\%. (McClure, 2005) also stated that investors are reluctant to those companies whose ROA is less than 5\%. (Dhanuskodi, 2014) also explained that as a fixed rule, expected level of ROA for companies is equal to or more than $5 \%$ which is considered good by banks.

The questionnaire mainly consists of two sections which are Section A and Section B. Section A consists of close ended questions "Yes" or "No", Code 1 represents "yes" and 0 represents "no". While Section B consists of 5 point Likert scale ranging from 1 equal to 'strongly disagreed' to 5 equal to 'strongly agreed' applied to evaluate firm's performance in CIDB Klang Valley. The sample size of 380 CIDB Klang Valley construction companies are targeted for the collection of primary data. Board of directors and senior management are targeted in this study because they are directly involved in the overall running of the businesses, and their views often represent the views of the entire firm's.

This is a cross sectional study and its focus is on measuring the effect of corporate governance mechanism on firm's performance in year 2015 using an improvised model which was first developed by Iskandar et al. (2011). Iskandar et al. (2011) postulates four variables: Board Composition, Duality Fuctions, Equity Ownership of Management and Equity Ownership of Institutional Investors are theoretically connected to firm's financial performance. As such, this study improvises Iskandar's model by incorporating five new variables and the detailed model is expressed as follows:

The final model that was fit to the data is given by,

$$
\mathrm{ROA}=\beta 0+\beta 1 B C+\beta 2 B S+\beta 3 R C+\beta 4 R M C+\beta 5 G D+\beta 6 O C+\beta 7 A C+\beta 8 D U+\varepsilon
$$

The SAS (9.4) statistical program is employed to test the relationship between dependent and independent variables with empirical model of logistic regression.

The above research model is estimated using Logistic Regression because of dichotomous nature of the dependent variable which is measured by return on asset (ROA). The five new variables added in the model contribute to the novelty elements in this corporate governance study. The details on the model specifications are explained in the following section.

\subsection{Measures}

The measurements of variables have been taken from earlier researchers. The Table 1 shows the list of primary data variables tested in this study with their data sources.

Table 1. Variables and data source

\begin{tabular}{|c|c|}
\hline Dependent variable & \\
\hline Return on Assets (ROA) & $\begin{array}{l}\text { Data source: Loth, 2005; McClure, 2005; Dhanuskodi, 2014, Hussain and } \\
\text { Hadi, } 2017\end{array}$ \\
\hline \multicolumn{2}{|l|}{ Independent variables } \\
\hline Board Composition (BC) & Data source: Chithambo, 2013., Andre et. al 2005, Hussain and Hadi, 2017 \\
\hline Remuneration committee (RC) & Data source: Hussain and Hadi, 2017 \\
\hline $\begin{array}{l}\text { Risk Management Committee Size } \\
\text { (RMC) }\end{array}$ & Data source: Hussain and Hadi, 2017 \\
\hline Gender Diversity (GD) & Data source: Hussain and Hadi, 2017. \\
\hline Ownership Concentration (OC) & Data source: Chithambo, 2013. Andre et. al 2005 \\
\hline Audit Committee (AC) & Data source: Chithambo, 2013. \\
\hline
\end{tabular}




\begin{tabular}{ll}
\hline Control variables & \\
Board Size (BS) & Data source: Hussain and Hadi, 2017. \\
Duality (DU) & Data source: Chithambo, 2013. \\
\hline
\end{tabular}

\section{Empirical Findings}

This section presents corporate governance mechanism involving eight elements: board composition, board size, remuneration committee, risk management committee, gender diversity, duality, ownership concentration and audit committee. All these predictor variables are analyzed against firm performance in each construction company.

A total of 380 contractors of construction industry agreed and have participated in the current research. Upon receiving the consent from CIDB head office, the survey questionnaires are then courier to state offices. During the survey, we observed that other states contractors also can submit their cases in Klang Valley sates as can be seen in Table 2.

The total respondents according to CIDB states are shown in Table 2.

Table 2. Respondents by State

\begin{tabular}{lll}
\hline States & Responses & \% \\
\hline Selangor & 183 & 48 \\
Wilayah Persekutuan & 159 & 42 \\
Melaka & 2 & 0.5 \\
Perak & 5 & 1 \\
Sabah and Sarawak & 6 & 2 \\
Pahang & 4 & 0.5 \\
Terengganu & 4 & 0.5 \\
Pulao Pinang & 7 & 2 \\
Johor Bahru & 3 & 1 \\
Perlis & 3 & 1 \\
Kedah & 2 & 0.5 \\
Kelantan & 1 & 0.5 \\
Klang & 1 & 0.5 \\
Total & 380 & 100 \\
\hline
\end{tabular}

The table reveals that major $48 \%$ respondents belong to Selangor and $42 \%$ to Wilayah Persekutuan. The results indicate that small and medium enterprises (SMEs) of construction industry highly located in the given two states.

The different types of grades are assigned to companies registered under CIDB. Grade 1 relates to small scale and then proceeds to large scale until grade 7 (CIDB, 2015). The breakdown of the respondents according to the level of grades (G1 to G7) and their measurements are listed in Table 3.

Table 3. Respondents by grades

\begin{tabular}{llll}
\hline Grade Registration & Construction Project Value (RM) & Respondents & Response rate \\
\hline G1 & 200,000 and less than & 32 & $9.0 \%$ \\
G2 & 200,001 to 500,000 & 51 & $14.0 \%$ \\
G3 & 500,001 to $1,000,000$ & 113 & $28.0 \%$ \\
G4 & $1,000,001$ to $3,000,000$ & 69 & $18.0 \%$ \\
G5 & $3,000,001$ to $5,000,000$ & 82 & $22.0 \%$ \\
G6 & $5,000,001$ to $10,000,000$ & 10 & $3.0 \%$ \\
G7 & More than $10,000,000$ & 23 & $6.0 \%$ \\
Total & & 380 & $100 . \%$ \\
\hline
\end{tabular}

Table 3 clearly shows that maximum respondents linked with G3 around $28 \%$ of the total sample size which is representation of the small scale of construction projects. The G7 representing $6 \%$ related to large scale projects. 
It means current study representing small scale construction companies at the majority level. It is consistent with (SMIDEC, 2008) that small scale companies help more to run the economy.

Gender information of the construction company is provided in Table 4.

Table 4. Respondents by Gender

\begin{tabular}{lll}
\hline Gender & Responses & \% \\
\hline Male & 250 & 66 \\
Female & 130 & 34 \\
Total & 380 & 100 \\
\hline
\end{tabular}

The figures presented in Table 4 imply that $66 \%$ respondents are male and the rest are female. This is aligned with the Malaysian government policy of having at least $30 \%$ female representation in the decision-making level of the corporate sector (Julizaerma and Zulkernain, 2012).

Table 5 provides information on the status of enterprise or Serdian Berhad construction company.

Table 5. Responses on enterprise / serdian berhad

\begin{tabular}{lll}
\hline Status & Responses & $\mathbf{\%}$ \\
\hline Enterprise & 129 & 34 \\
Sendirian Berhad & 251 & 66 \\
Total & 380 & 100 \\
\hline
\end{tabular}

$66 \%$ are registered as Sendirian Berhad and the rest are enterprises. The small and medium enterprises (SMEs) are the backbone of Malaysia's economy. According to Finance Minister II Datuk Seri Ahmad Husni Mohamad Hanadzlah, SMEs comprise $99.2 \%$ of the total registered business establishments in the country and contribute $56.4 \%$ to employment. They contributed $32 \%$ to gross domestic product (GDP) and $19 \%$ of total exports for the year 2005 (SMIDEC, 2008).

Table 6 provides information about the nature of ownership and management of construction companies.

Table 6. Responses on ownership

\begin{tabular}{lll}
\hline Management by & Responses & \% \\
\hline Directors & 376 & 99.9 \\
Managers & 4 & 0.1 \\
Total & 380 & 100 \\
\hline
\end{tabular}

99.9\% of the respondents indicated that CIDB construction sector is managed by directors and $0.1 \%$ by managers. The result is consistent with Bruce et. al. (1998) who found that more than $80 \%$ of small businesses are family-owned.

Table 7. Descriptive Statistics for variables

\begin{tabular}{llll}
\hline Variables & Dimensions & Respondents & Percentage \\
\hline Board composition & Strongly Disagree & 10 & 2.63 \\
& Disagree & 4 & 1.05 \\
& Neutral & 180 & 47.37 \\
& Agree & 181 & 47.63 \\
Board committee size & Strongly Agree & 5 & 1.32 \\
& Strongly Disagree & 6 & 1.58 \\
& Disagree & 9 & 2.37 \\
& Neutral & 186 & 48.95 \\
& Agree & 174 & 45.79 \\
Remuneration committee & Strongly Agree & 5 & 1.32 \\
& Strongly Disagree & 6 & 1.58 \\
\hline
\end{tabular}




\begin{tabular}{|c|c|c|c|}
\hline \multirow{8}{*}{ Risk management committee } & Disagree & 16 & 4.21 \\
\hline & Neutral & 188 & 49.47 \\
\hline & Agree & 165 & 43.42 \\
\hline & Strongly Agree & 5 & 1.32 \\
\hline & Strongly Disagree & 9 & 2.37 \\
\hline & Disagree & 12 & 3.16 \\
\hline & Neutral & 209 & 55.00 \\
\hline & Agree & 145 & 38.16 \\
\hline \multirow{3}{*}{ Gender diversity } & Strongly Agree & 5 & 1.32 \\
\hline & Strongly Disagree & 9 & 2.37 \\
\hline & Disagree & 7 & 1.84 \\
\hline \multirow{7}{*}{ Duality } & Neutral & 206 & 54.21 \\
\hline & Agree & 147 & 38.68 \\
\hline & Strongly Agree & 11 & 2.89 \\
\hline & Strongly Disagree & 6 & 1.58 \\
\hline & Disagree & 14 & 3.68 \\
\hline & Neutral & 209 & 55.00 \\
\hline & Agree & 146 & 38.42 \\
\hline \multirow{4}{*}{ Ownership concentration } & Strongly Agree & 5 & 1.32 \\
\hline & Strongly Disagree & 6 & 1.58 \\
\hline & Disagree & 6 & 1.58 \\
\hline & Neutral & 216 & 56.84 \\
\hline \multirow{7}{*}{ Audit committee } & Agree & 147 & 38.68 \\
\hline & Strongly Agree & 5 & 1.32 \\
\hline & Strongly Disagree & 6 & 1.58 \\
\hline & Disagree & 18 & 4.74 \\
\hline & Neutral & 207 & 54.47 \\
\hline & Agree & 138 & 36.32 \\
\hline & Strongly Agree & 11 & 2.89 \\
\hline
\end{tabular}

Table 7 shows the numerical analysis of responses received from primary data based on likert scale. The respondents show their perception about corporate governance mechanism in Construction Industry Development Board (CIDB) Malaysia registered companies. Audit committee again got good responses (54.7\%) which highly recommend its presence to govern the risks on periodic basis in a construction company.

The Cronbach's Alpha is used to assess the internal scale consistency. In addition, the Krippendorff Alpha has been calculated to increase reliability of content analysis findings. The Krippendorff Alpha obtained is 0.80 and this compares favorably to the minimum agreed threshold of the 0.70 (Krippendorff, 2004).

Table 8. Cronbach's Alpha test for the study

\begin{tabular}{lll}
\hline Variables & $\begin{array}{l}\text { Cronbach's } \\
\text { value }\end{array}$ & $\begin{array}{l}\text { alpha } \\
\text { Cronbach's alpha item } \\
\text { wise } \\
\text { Stand. } \\
\text { Likert Scale }\end{array}$ \\
\hline Board composition (BC) & & 0.788 \\
Board committee size (BC) & & 0.778 \\
Remuneration sub-committee (RC) & & 0.767 \\
Risk management committee size (RMC) & & 0.774 \\
Gender diversity (GD) & 0.806 & 0.775 \\
Firm's performance (ROA) & & 0.833 \\
Duality (DU) & & 0.769 \\
Ownership concentration (OC) & & 0.771 \\
Audit committee (AC) & & 0.780 \\
\hline
\end{tabular}


Table 8 shows that all the variables scored above 0.7 for reliability and the overall value of Cronbach's Alpha is 0.806. It means the questionnaire data is reliable.

Factor analysis is also carried out to find the minimum number of factors that breed the best perceived correlations and also offer a serious or interpretable combination of the variables. These lowest numbers of unrealized latent variables are known as factors. A commonly used criterion of eigenvalues greater than 1 is employed to determine the number of factors (Kundari et. al., 2012). Section A of the questionnaire represents categorical data and section B represents continuous data from the questionnaire. Eight items of corporate governance are subject to principal component analysis (PCA) using SAS (9.4).

Table 9. Factor correlation matrix

\begin{tabular}{lllllllll}
\hline & BC & BCS & RC & RMC & GD & DU & OC & AC \\
\hline BC & 1.0000 & & & & & & & \\
BCS & 0.7636 & 1.0000 & & & & & & \\
RC & 0.7618 & 0.7811 & 1.0000 & & & & & \\
RMC & 0.1459 & 0.3249 & 0.2920 & 1.0000 & & & & \\
GD & 0.1465 & 0.1443 & 0.3471 & 0.6527 & 1.0000 & & & \\
DU & 0.1942 & 0.2053 & 0.3772 & 0.6702 & 0.7709 & 1.0000 & & \\
OC & 0.2171 & 0.2431 & 0.3296 & 0.7111 & 0.7461 & 0.7378 & 1.0000 & \\
AC & 0.0904 & 0.2634 & 0.3034 & 0.6332 & 0.6058 & 0.5459 & 0.6228 & 1.0000 \\
\hline
\end{tabular}

Table 9 indicates that all factors have a positive correlation factor matrix with corporate governance mechanism (board composition, board committee size, remuneration sub-committee, risk management committee, gender diversity, duality, ownership concentration, audit committee).

Table 10. Logistic Regression Results

\begin{tabular}{|c|c|c|c|c|}
\hline \multirow[b]{2}{*}{ Parameter } & \multicolumn{4}{|c|}{ Primary data } \\
\hline & & Estimate & P-value & Odds Ratio \\
\hline Intercept & Expected sign & -0.9052 & 0.2686 & \\
\hline $\mathrm{BC}$ & + & 0.5427 & 0.0852 & 1.721 \\
\hline BS & + & -0.00818 & 0.9826 & 0.992 \\
\hline $\mathrm{RC}$ & - & 0.1961 & 0.5859 & 1.217 \\
\hline $\mathrm{RMC}$ & + & -0.3338 & 0.2774 & 0.716 \\
\hline GD & + & -0.4505 & 0.1532 & 0.637 \\
\hline DU & - & 1.2009 & $* 0.0006$ & 3.323 \\
\hline $\mathrm{OC}$ & - & -1.4221 & $*<.0001$ & 0.241 \\
\hline $\mathrm{AC}$ & + & 0.6309 & $* 0.0144$ & 1.879 \\
\hline Cox and Snell Pseudo $\mathrm{R}^{2}$ & & 0.1123 & & \\
\hline Nagelkerke $\mathrm{R}^{2}$ & & 0.1507 & & \\
\hline
\end{tabular}

\footnotetext{
*significant at 5\% level.
} 
Results from Table 10 show that Cox and Snell Pseudo R-square and Nagelkerke R-square have low value for the data. Nagelkerke R-square is 0.1507 indicating that the independent variables in the model explain $15 \%$ of the change in the dependent variable. Based on the statistical results from the continuous data as shown in Table 4.18, audit committee (AC), duality (DU) and ownership concentration (OC) bear statistically significant coefficients at $5 \%$ level.

It is imperative to note that a credible corporate governance mechanism does involve the operations of duality (DU). As such, the presence of AC of a company is a transcending process that signals not only improvement in the company's accountability but also its level of transparency. Through diversified analysis, the p-value of most of the variables are significant, which represents that corporate governance model has a high impact on firm's performance with the significance of DU, AC and OC in the small and medium scale construction industry in Malaysia.

An odds ratio is a statistical technique that measures the degree of association between an exposure and an outcome (Allison, 2010). Table 10 also shows the odd ratios from continuous data. The projected odds ratio of board composition is 1.72 times higher than the odds of other variables. The projected odds ratio of remuneration committee is 1.21 times the odds for other variables. As such, the odds that firm's performance being influenced by remuneration committee is $21 \%$ higher than the odds for other variables in the model.

The projected odds ratios of duality and audit committee are 3.32 and 1.87 times higher than the odds of other variables. Likewise, the odds that duality and audit committee improves firm's performance are more that $32 \%$ as compared to other variables. The odds ratios of board size, risk management committee, gender diversity and ownership concentration are less than 1, which highlights that the influence of these variables on firm's performance is not much as compared to other variables.

\section{Discussion and Conclusion}

It is evident from the empirical results that board size has no significant impact in case of secondary data which is in line with Julizaerma and Zulkernain (2012). The results suggest that board composition has no significant impact in case of secondary data which is in line with (Core and Larcker, 2002). The results also show that remuneration committee has no significant impact which is in line with Basiru (2015), explains that risk management committee (RMC) has insignificant relationship on firm's financial performance (ROA). It clears from the findings that gender diversity has no significant impact which is in line with Wang and Clift (2009), found that there is no significant relationship between gender diversity (women directorship) and firm's performance.

Here one point is notable that audit committee (AC) is significant which is inline with Wild (1994) finds that the formation of associates combination of the audit committee will increase share returns that show a positive relationship. Another variable duality also significant positive which is consistent with Dahya et. al. (1996) reported a positive association between separating the roles of chairman and business executive and monetary performance. Similarly, Daily and Dalton (1994) noticed that business executive duality is an important issue for the companies that faced bankruptcy. The ownership concentration also significant negative results which is agreed with Al-Twaijry et al. (2002), stakeholders in Asian economies like sub-committees, audit committees, to protect shareholders' interests. Claessens et al. (2002) indicated that major shareholders negatively affected corporate governance performance and implementation.

Though the study has theoretical contributions to the literature, like so far, no study exists related to return on asset measured as a binary variable in corporate governance characteristics. This study is the first effort explaining corporate governance issue in CIDB Malaysia registered companies with regards to return on assets as a binary variable. It also consists of quite a few limitations. Initially, the sample size (380 observations) is not small compared to the samples employed in previous studies on Malaysian companies like Kundari et. al. (2012) examined 78 observations. Though the sample employed in this study is sensible as compared to previous studies, the generalizability of the findings may be improved if the sample size is larger. A very limited amount of respondents of CIDB registered companies take part which makes it harder to recognize the population represented by the given sample. The results cannot be generalized. Second, only Wilayah Persekutuan and Negeri Selangor shows good proportion but others contribution very less. Only directors or managers of the entities are chosen to gather the data for the research.

Although the directors or managers may be the main person in the small enterprises, an individual's ability cannot represent the whole approach of the entity. Furthermore, the perceptual thoughts of the directors or 
managers may be partial because of their independent judgments. The study measures the effect of corporate governance mechanism and firm's performance with the analysis of primary as well as secondary data. Only a single technique, return on assets (ROA) applied to measure the firm's performance. Previous studies explain that a return on equity is a better technique (Hutchinson and Gul, 2004) and Saleh et al. (2012). However, it is not significantly related to corporate governance reporting. The validity of the results could be increased if the study used more than one accounting measure for firm's performance.

\section{References}

Allison, P. D. (2010). Logistic Regression Using SAS: Theory and Application (9th ed.). SAS Institute and Wiley.

Al-Twaijry, M., Brierley, A., \& Gwilliam, R. (2002). An Examination of the Role of Audit Committees in the Saudi Arabian Corporate Sector. Corporate Governance: An International Review, 10(4), 288-297. https://doi.org/10.1111/1467-8683.00293

Andre, L. C., \& Ricardo, P. C. (2005). Corporate Governance Index, Firm Valuation and Performance in Brazil. Revista Brasileira de Financ as 2005, (1), 1-1.

Anthony, K. C., \& Kofi, A. O. (2008). Outreach and profitability of microfinance institutions: the role of governance. Journal of Economics Studie. https://doi.org/10.1108/01443580810887797

Armstrong, A., \& Sweeney, M. (2002). Enhancing Corporate Governance: Demonstrating Corporate Social Responsibility through Social Reporting. Governance and Corporate Social Responsibility in the New Millenium Conference Proceedings (Deakin University, Victoria, Australia) pp. 1-15.

Basiru, S. K. (2015). Risk Management Committee Attributes and Firm's Performance International Finance and Banking. http://dx.doi.org/10.5296/ifb.v2i2.8580

Beasley, M. S. (1996). An Empirical Analysis of the Relation between the Board of Director Composition and Financial Statement Fraud. Accounting Review, 71, 443-455.

Ben, M. (2005). ROA and ROE give clear picture of Corporate Health. Retrieved from $\mathrm{http}: / / \mathrm{www}$.investopedia.com/articles/basics/05/052005.asp

Bilal, L., Muhammad, N. S., Muhammad. Z., Hafiz. M. W., \& Arbab, A. (2013). Impact of Corporate Governance on Firm Performance: Evidence from Sugar Mills of Pakistan. European Journal of Business and Management, 5(1).

BNM. (1999). The Central Bank and The Fianncial System in Malaysia - A Decade of Change. Kuala Lumpur. Bank Negara Malaysia. $\quad$ Retrieved from http://www.bnm.gov.my/index.php?ch=en_press\&pg=en_press\&ac=1337\&lang=en

BNM. (2007). Annual Report 2006. Kuala Lumpur. The Central Bank of Malaysia. Retrieved from http://www.bnm.gov.my/index.php?ch=en_publication\&pg=en_ar\&ac=13

Bruce, A., Poutziouris, P., \& Binks, M. (1998). A Problem-based Phenomenological growth model for small manufacturing firm. Retrieved from http//www.emarldsight.com.

Catalyst. (2008). Catalyst Census of Women Boards Directors of the Fortune 500. New York, NY. Retrieved from $\mathrm{http}: / /$ www.catalyst.org/knowledge/2013-catalyst-census-fortune-500-women-board-directors

Chang, S. J. (2003). Ownership Structure, Expropriation, and Performance of Group-Affiliated Companies in Korea. Academy of Management Journal, 46(2), 238-253.

Chithambo, L. C. (2013). The Extent and Determinants of Greenhouse Gas Reporting in the United Kingdom. Retrieved from http://eprints.bournemouth.ac.uk/21380/.

Chowdary, T. H. (2002). Interconections Dispoute: Basic considerations. Economic and Political Weekly, 37(41), 4184-4186.

Chris, O., Dimitrios. N. K., \& Maria. A. (2009). Board characteristics and involvement in strategic decision making: The Nigerian perspective. Management Research News, 32(2), 169-184. https://doi.org/10.1108/01409170910927622

CIDB. (2015). Construction Industry Development Board Malaysia. Buku Keperluan Dan Procedur Pendaftaran Kontraktor, 2015. Retrieved from http://www.cidb.gov.my/index.php/en.

Claessens, S., \& Fan, J. (2002). Corporate Governance in Asia: A Survey. International Review of Finance, 3(2), 71-103. https://doi.org/10.1111/1468-2443.00034 
Collins. G. N., Kwaku, K. O., Jo, D., \& Dennis, A. T. (2012). Voluntary corporate governance disclosures by post-Apartheid South African corporations. Journal of Applied Accounting Research.

Core, J. E., \& Larcker, D. F. (2002). Performance consequences of mandatory increases in executive stock ownership. Journal of Financial Economics, 64, 317-340.

Dahya, J., Lonie, A., \& Power, D. (1996). The Case for Separating the Roles of Chairman and CEO: An Analysis of Stock Market and Accounting Data. Corporate Governance: An International Review, 4(2), 71-77.

Daily, C., \& Dalton, D. (1994). Bankruptcy and Corporate Governance: The Impact of Board Composition and Structure. Academy of Management Journal, 37(6), 1603-1617.

Dalton, D. R., Daily, C. M., Johnson, J., \& Ellstrand, A. E. (1999). Number of directors and financial performance: A meta-analysis. Academy of Management Journal, 42(6), 674-687.

Dalton, D., Daily, C., Ellstrand, A., \& Johnson, J. (1998). Meta-analytic review of board composition, leadership structure, and financial performance. Strategic Management Journal, 19, 269-290.

Davidson, W. N., Xie, B., \& Xu, W. (2004). Markert reaction to voluntary announcements of audit committee appointments: the effect of financial expertise. Journal of Accounting and Public Policy, 23, 279-293.

Dhanuskodi, R. (2014). Impact of Loan Deposit Ratio on Profitability: Panel Evidence from Commercial Banks in Malaysia. In Proceedings of the Third International Conference on Global Business, Economics, Finance and Social Sciences, Mumbai, India.

Donaldson, L., \& Davis. (1994). Boards and Company Performance: Research Challenges the Conventional Wisdom. Corporate Governance, An International Review, 2(3), 151-160.

Donaldson, L., Davis, J. H., \& Schoorman, F. D. (1997). Towards a Stewardship Theory of Management. Academy of Management Review, 22(1), 20-47.

Fraser, I., Henry, W. (2007). Embedding risk management: Structures and approaches. Managerial Auditing Journal 22(4), 392-409. https://doi.org/10.1108/02686900710741955

Haniffa, R., \& Hudaib, M. (2006). Corporate Governance Structure and Performance of Malaysian Listed Companies. Journal of Business Finance and Accounting, 33, 1034-1062.

Hermalin, B., \& Weisbach, M. (1991). The Effects of Board Composition and Direct Incentives on Firm's Performance. Financial Management, 20(4), 101-112.

Hunt, L. (2010). More room for women s participation in decision-making. The Star. Retrieved from http://biz.thestar.com.my/

Hussain, M. A., \& Hadi, A. R. (2017). Corporate Governance and Firm Performance: Evidence from CIDB Malaysia. American Journal of Research Communication, 5(12).

Hutchinson, M., \& Gul, F. A. (2004). Investment opportunity set, corporate governance practices and firm's performance. Journal of Corporate Finance, 10, 595-614.

Iskandar, T. M., Norazura, M., \& Saleh, M. (2011). Corporate governance and going concern problems: evidence from Malaysia. Int. J. Corporate Governance, 2(2).

Jensen, M. (1993). The modern industrial revolution, exit, and the failure of internal control systems. Journal of Finance, 48, 831-880.

Jensen, M. C., \& Meckling, W. H. (1976). Theory of the firm: managerial behavior, agency costs and ownership structure. Journal of Financial Economics, 3, 305-360.

Joshua, A., \& Nicholas, B. (2007). Corporate governance, ownership structure and performance of SMEs in Ghana: Implications for financing opportunities. The International Journal Of Business In Society, 7(3).

Julizaerma \& Zulkernain. (2012). Gender diversity in the board room and firm performance of Malysian Public Listed Companies. Procedia-Social and Behavioral Sciences, 65, 1077-1085. https://doi.org/10.1016/j.sbspro.2012.11.374

Kamini, S. (2003). Corporate Governance in Malaysia. Bond Law Review, 15(1). Retrieved from http://epublications.bond.edu.au/blr/vol15/iss1/13

Kevin, K., Helen, S., \& Robert, W. (1994). Directors ownership and firm performance of the small and medium sized firm in the UK. Small Business Economics, 3, 305.

Kiel, G., \& Nicholson, G. (2003). Board Composition and Corporate Performance: How the Australian 
experience informs contrasting theories of corporate governance. Corporate Governance: An International Review, 11(3), 189-205.

Kole, S. R., \& Mulherin, J. H. (1997). The Government as a Shareholder: A Case from the United States. Journal of Law and Economics, 60(1), 1-22.

Krejcie, R. V., \& Morgan, D. W. (1970). Determining Sample Size for Research Activities. Educational and Psychological Measurement.

Krippendorff, K. (2004). Content Analysis, an Introduction to Its Methodology (2nd ed.). Thousand Oaks, CA: Sage Publications.

Kundari, S., Ismail, S. A., \& Saleh, N. M. (2012). Computerized Accounting System at the MARA State Offices: Factors Affecting User Satisfaction And Job Performance. IRACST- International Journal of Research in Management and Technology (IJRMT), 2(6).

Laing, D., \& Weir, M. C. (1999). Governance structures, size and corporate performance in UK firm. Management Decision, 37(5), 457-464.

Lavender, S. (1996). Management for the construction industry. England, Longman.

Lei, L., \& Teen, M. Y. (2005). The Determinants of Corporate Governance and the Link between Corporate Governance and Performance: Evidence from the U.K. Using a Corporate Governance Scorecard. Working Paper, 18th Asian Pacific Conference.

Leng, A. C. A. (2004). The impact of corporate governance practices on firm's financial performance: evidence from Malaysian companies. ASEAN Economic Bulletin, 21(3), 308-318. http://www.jstor.org/stable/25773828

Leuz, C., Lins, K. V., \& Warnock, F. E. (2008). Do Foreigners Invest Less in Poorly Governed Firm's. ECGI Finance Working Paper.

Lipton, M., \& Lorsch, J. (1992). A Modest Proposal for Improved Corporate Governance. Business Lawyer, 48(1), 59-77. http://www.jstor.org/stable/40687360

Loth, R. (2005). Profitability Indicator Ratios: Return on Assets. Rerieved from http://www.investopedia.com/university/ratios/profitability-indicator/ratio3.asp

Luo, X., \& Chi, N. C. (2007). The Influence of Corporate Governance Models on Business Group Restructuring in Emerging Economies. Organization Science, 19(5).

Manakotla, K., \& Jauhari, V. (2007). Exploring Consumer Attitude and Behaviour Towards Green Practices in the Lodging Industry in India. International Journal of Contemporary Hospitality Management.

Maran, M., \& Indraah, K. (2009). Ethnicity and Gender Diversity in Boards of Directors and Their Relevance to Financial Performance of Malaysian Companies. Journal of Sustainable Development, 2(3), 139-148.

Masood, F., Zaleha, A., \& Norman, M. S. (2013). The effect of corporate governance and divergence between cash flow and control rights on firm performance: Evidence from Malaysia. International Journal of Disclosure and Governance, 11(4), 326-340.

MCCG.(2000).Malaysian Code on Corporate Governance. Securities Commission Kuala Lumpur. Retrieved from https://www.scribd.com/document/58277335/MCCG-2000-Finance-Comm.

McConaughny, D. L., Matthews, C. H., \& Fialko, A. S. (2001). Founding Family Controlled Firm's: Performance, Risk, and Value. Journal of Small Business Management, 39(1), 31-49.

Morck, R., Shleifer, A., Vishny, R. (1988). Management ownership and market valuation: an empirical analysis. Journal of Financial Economics, 20, 293-315.

Muhammad, T., Abdullah, S., \& Shukor, M. (2009). A study on directors' remuneration and board committee in Malaysia. Journal of Modern Accounting and Auditing, 5(1).

Rezaee, Z. (2009). Corporate Governance and Ethics. John Wiley and Sons, 2009 - Business and Economics- 448 pages.

Roche, J. (2005). Corporate Governance in Asia. The Asia pacific Journal of Ecomonics and Business, 9.

ROSC. (2012). Report on the Observance of Standards and Codes (ROSC), Corporate Governance Country Assessment. World Bank, Washington, US. Rerieved from http://documents.worldbank.org/curated/en/703091468088742465/Malaysia-Report-on-theObservance-of-S 
tandards-and-Codes-ROSC-accounting-and-auditing

Saleh, N. M., \& Zuraidah, R. (2012). Firm's performance, CEO tenure and Corporate Governance Reporting in Malaysia. Int. J. Management Practice, 5(2).

Saleh, N. M., Iskandar, T. M., \& Mohd, M. R. (2007). Audit committee characteristics and earnings management: evidence from Malaysia. Asian Review of Accounting, 15(2), 147-163.

Shamser, \& Zulkarnain, M. S. (2001). Role of audit committees in a disclosure based corporate environment. Akauntan Nasional, 16-18.

SMIDEC. (2008). Promoting Innovation - led and Technology - Driven SMEs. Paper Presented in Asia Pacific Conference of Technology and Technology Entrepreneurship.

Soares, R., Combopiano, J., Regis, A., Shur, Y., \& Wong, R. (2010). 2010 Catalyst Census: Fortune 500 Women Board Directors. Retrieved from http://www.catalyst.org

Solomon, J. (2010). Corporate Governance and Accountability (2nd ed.). Hoboken, NJ, Wiley, Chichester, UK.

Steen. T. (2004). Corporate values and corporate governance. The International Journal of Business in Society.

Sundaraj, G. (2006). A brief in the construction post independent day in Malaysia, particularly, from the year of 1957 until now. CIDB News, 3.

Sundaram, I. (2004). The Corporate Objective Revisited. Organization Science, 15(3), 350-363.

Tan, K. L. (2004). Evolution of the Construction Industry in Malaysia. Master Builders, 56-57.

The Financial Aspects of Corporate Governance: Cadbury Report 1992. Retrieved from http://www.ecgi.org/codes/documents/cadbury.pdf

Ujunwa. A. (2012). Board characteristics and the financial performance of Nigerian quoted firms. The International Journal of Business in Society, 12(5).

Veysel. K, \& Ekrem, T. (2006). Board process attributes and company performance of family-owned businesses in Turkey. The International Journal of Business in Society, 6(5). https://doi.org/10.1108/14720700610706108

Wang, Y., Clift, B. (2009). Is There A Business Case For Board Diversity? Pacific Accounting Review, 21(2), 88-193. https://doi.org/10.1108/01140580911002044

Weir, C., \& Laing, D. (2001). Governance Structures, Director Independence and Corporate performance in the UK. European Business Review, 13(2), 86-94.

Wild, J. (1994). Managerial Accountability to Shareholders: Audit Committees and the Explanatory Power of Earnings for Returns. British Accounting Review, 26(4), 353-374.

Yammeesri, J., \& Lodh, S. C. (2001). The Effects of Ownership Structure on Firm's Performance: Evidence from Thailand. Hawaii International Conference on Business.

Yatim, P. (2010). Board structures and the establishment of a risk management committee by Malaysian listed firm. Journal of Management $\quad$ Governance $14(1), \quad 36$. https://link.springer.com/article/10.1007/s10997-009-9089-6

\section{Copyrights}

Copyright for this article is retained by the author(s), with first publication rights granted to the journal.

This is an open-access article distributed under the terms and conditions of the Creative Commons Attribution license (http://creativecommons.org/licenses/by/4.0/). 